\title{
Identification of anti-diabetic complication products from green tea induced by cold plasma
}

\author{
Gyeong Han Jeong ${ }^{1}$, Youjeoung Lee ${ }^{1}$, Sunghyun Kim ${ }^{1}$, Seungil Park ${ }^{2}$, \\ Seong Bong $\mathrm{Kim}^{2}$, Tae Hoon $\mathrm{Kim}^{1 *}$ \\ ${ }^{1}$ Department of Food Science and Biotechnology, Daegu University, Gyeongsan 38453, Korea \\ ${ }^{2}$ Plasma Technology Research Center, National Fusion Research Institute, Gunsan 54004, Korea
}

\section{저온 플라즈마 처리된 녹차 유래의 최종당화산물 생성 억제물질의 동정}

\author{
정경한 $^{1} \cdot$ 이유정 ${ }^{1} \cdot$ 김성현 $^{1} \cdot$ 박승일 $^{2} \cdot$ 김성봉 $^{2} \cdot$ 김태훈 $^{1 *}$ \\ ${ }^{1}$ 대구대학교 식품공학과, ${ }^{2}$ 국가핵융합연구소 플라즈마기술연구센터
}

\begin{abstract}
Green tea (Camellia sinensis) with abundant phenolic compounds is considered to a major dietary source of flavan 3-ols such as (-)-epigallocatechin gallate (EGCG). Here, we assessed the effects of non-thermal dielectric barrier discharge (DBD) plasma on green tea extract using spectroscopy and bioassays. Plasma-induced structural changes in EGCG in green tea resulted in the isolation of two methylene-bridge dimers, oolonghomobisflavan A (1) and $B$ (2). The structures of these compounds were characterized using nuclear magnetic resonance and mass spectroscopy data. The symmetric dimer 1 connected by a methylene linkage was the most potent inhibitor of advanced glycation end products (AGEs) formation $\left(\mathrm{IC}_{50}, 8.2 \pm 0.5 \mu \mathrm{M}\right)$. The radical scavenging capacity of against hydroxyl, and stereoisomers 1 and 2 was more potent than that of the positive control $((+)$-catechin). These major products purified by treating green tea with DBD plasma for $60 \mathrm{~min}$ were quantified by HPLC. Our results provide evidence that structural changes of EGCG in green tea extract induced by plasma might enhance biological efficacy.
\end{abstract}

Key words : green tea, EGCG dimer, cold plasma, AGEs formation, hydroxyl radical

\section{서 론}

당뇨합병증은 장기간의 당뇨병으로 인하여 hyperglycemia 이외에 여러 가지 요인에 의해 유발되는 만성의 질환으로 당 뇨병 발병률의 증가함에 따라 당뇨합병증 역시 증가하는 추세 이다(Rahimi 등, 2005). 당뇨합병증의 발병 기전으로는 poly pathway flux 및 protein kinase $\mathrm{K}(\mathrm{PKC})$ isoform의 활성화와 최종당화산물(advanced glycation end products, AGEs)의 생 성 증가 등이 있으며, 이러한 대사 과정은 활성산소종(reactive oxygen species)의 생성과 깊은 상관관계가 있다(Cho 등,
2007). 특히 당뇨로 인해 hyperglycemia가 장기간 지속됨에 따라 인체 조직 내에서 AGEs가 생성되는데, 한번 생성된 AGEs는 쉽게 분해되지 않는다. 또한, 생성된 AGEs는 혈액 단백질이나 여러 조직에 교차 결합하여 다양한 합병증을 유 발한다(Singh 등, 2001). 현재까지 잘 알려진 AGEs 생성 저 해제로는 aminoguanidine이 있으나, 임상시험에서 독성을 나 타냄이 보고됨에 따라 보다 안전하고 부작용인 적은 $\mathrm{AGEs}$ 생성 재해 물질의 개발이 요구되고 있다(Ahmed, 2005). 최근 천연 식의약 소재로부터 AGEs 생성 저해제의 개발 연구가 활발히 진행되고 있으며(Matsuda 등, 2003), 석류(Punica

*Corresponding author. E-mail : skyey7@daegu.ac.kr, Phone : +82-53-850-6533, Fax : +82-53-850-6539

Received 14 August 2020; Revised 01 September 2020; Accepted 02 September 2020.

Copyright (c) The Korean Society of Food Preservation.

This is an Open Access article distributed under the terms of the Creative Commons Attribution Non-Commercial License (http://creativecommons.org/licenses/by-nc/4.0) which permits unrestricted non-commercial use, distribution, and reproduction in any medium, provided the original work is properly cited. 
granatum) 추출물로부터 강한 AGEs 저해능을 나타낸 ellagitannin 유도체가 구조 결정되었고(Ito 등, 2014), 다래 (Actinidia arguta)로부터 AGEs 생성을 효과적으로 저해하는 신규 flavoalkaloid류의 화합물이 보고가 되었다(Jang 등, 2009).

최근 개발된 여러 종류의 저온 플라즈마 처리 장치 중 dielectric barrier discharge(DBD) 플라즈마는 대기압 상태에 서 유전체 장벽 사이에 전압을 방전시켜 낮은 온도에서 플라 즈마가 발생된다(Misra 등, 2011). 발생된 플라즈마에는 이 온, 전자, 오존, 자외선 및 다양한 활성산소종 등이 다량 생성 (Ji 등, 2018)되며, 미생물 성장을 억제시키는 기능이 있어 식 품의 진보된 비열 살균법으로 주목 받고 있다(Oehmigen 등, 2010). 또한, 이전 연구에서는 살균 이외에도 식품의 물리 화 학적 특성 변화를 유도하는 것으로 보고 되어있다(Pankaj 등, 2018). 이전 연구에서 블루베리 주스에 저온 플라즈마를 처 리한 결과 Bacillus 속 미생물의 사멸을 유도하였으며 무처리 군에 비해 상승된 항산화 활성이 보고가 되었다(Hou 등, 2019). 또한, 플라즈마 처리된 석류(Punica granatum) 주스 는 무처리군에 비해 anthocyanin 함량이 $10 \%$ 이상 증가하였 으며, 색소의 변화가 확인하였다(Kovacevic 등, 2016). 독성 성분의 저감화 기술의 일환으로 곡물에서 자연적으로 발생하 는 독성 물질인 T-2 및 HT-2 독소는 저온 플라즈마에 의해 쉽게 분해되는 것이 보고되었다(Kis 등, 2020).

차(Camellia sinensis)는 음료의 일종으로 가공방법 및 발 효상태에 따라 녹차, 백차, 홍차 및 흑차 등으로 나뉘는데, 그 중에서 발효시키지 않은 찻잎을 사용하여 만든 차를 녹차라 고 한다(Mineharu 등, 2011). 녹차의 원산지는 중국의 산악지 대로 알려져 있으며, 한국에서는 삼국시대 후반부터 소비한 것으로 알려져 있고, 현재에는 보성군 및 하동군이 주요 원산 지로 잘 알려져 있다(Shin, 1989). 녹차의 주요 성분은 caffeine 과 함께 쓴맛을 내는 catechin류의 화합물이 다량 함유되어 있는 것으로 알려져 있으며, 특히 (-)-epigallocatechin gallate (EGCG)가 풍부하게 함유되어 있고(Seeram 등, 2006), 항산 화(Wanasundara과 Shahidi, 1998), 항암(Azam 등, 2004) 및 항염증(Lambert 등, 2010) 등의 다양한 기능성 활성 등이 보 고되어 있다(Hu 등, 2018). 최근 연구에서 녹차에 비열 가공 방법인 감마선 조사를 수행한 결과, 무처리군에 비해 상승된 라디칼 소거 및 tyrosinase 저해활성이 보고가 되었다(Lee 등, 2006). 본 연구에서는 비열 살균법으로 주목받고 있는 저온 플라즈마를 녹차 추출물에 처리하였으며, 당뇨합병증과 관련 된 AGEs 생성 저해능 및 hydroxyl 라디칼 소거능 평가를 수 행하였다. 그 결과, 플라즈마 처리군에서 상승된 항당화 활성 을 확인하였으며, 신규 생성된 화합물을 각종 칼럼크로마토 그래피 및 기기분석을 이용하여 구조 결정하였다. 분리된 단
일물질에서 강한 AGEs 생성 저해 및 hydroxyl 라디칼 소거 활성을 확인하였기에 그 결과를 보고하고자 한다.

\section{재료 및 방법}

\section{재료 및 기기}

본 실험에 사용한 녹차(Camellia sinensis)는 전라남도 보 성군에서 2012년 9월에 채취한 건조된 것을 사용하였다. 먼 저 건조된 녹차 $(200 \mathrm{~g})$ 를 증류수 $2 \mathrm{~L}$ 에 침지시킨 후 $90^{\circ} \mathrm{C}$ 에 서 3 시간 동안 열수 추출 후 저온 감압 농축기를 이용하여 농축하였다. 정량평가 및 기능성 평가에 사용된 caffeine, (-)-epigallocatechin gallate(EGCG), bovine serum albumin (BSA), aminoguanidine, dexoyribose 및 (+)-catechin 등의 시약은 Sigma-Aldrich Chemical Co.(St. Louis, MO, USA) 에서 구입하여 사용하였다. 물질 분리에는 역상 HPLC(LC20A, Shimadzu, Tokyo, Japan)를 사용하였고, ${ }^{1} \mathrm{H},{ }^{13} \mathrm{C}$ NMR 과 $\mathrm{HSQC}$ 및 $\mathrm{HMBC}$ 스펙트럼은 acetone- $d_{6}\left(\delta_{\mathrm{H}} 2.04, \delta_{\mathrm{C}}\right.$ 29.8) 용매를 이용하여 $600 \mathrm{MHz}$ 의 NMR spectrometer (FT-NMR, Varian VNS600, Palo alto, CA, USA)로 측정하 였으며, 분석 및 column chromatography용 용매는 특급시약 을 사용하였다. FABMS 스펙트럼은 JMS-700 GC-HRMS (JEOL, Tokyo, Japan)를 활용하여 분자량을 측정하였다.

\section{플라즈마 처리 및 생성물질의 분리}

녹차 열수추출물 $(200 \mathrm{mg})$ 을 에탄올 $500 \mathrm{~mL})$ 에 녹인 후 dielectric barrier discharge(DBD)(2.5 kHz, 4.0 Vpp, Plasma Technology Research Center, National Fusion Research Institute, Gunsan, Korea) 플라즈마 처리기기를 이용하여 20, 40 및 60 분 동안 플라즈마 처리 후 농축하였다(data not shown). 각 시간별 플라즈마 처리된 녹차 반응물을 대해 AGEs 생성 저해 활성 평가를 수행하였으며, 60 분 플라즈마 처리된 녹차 반응물에서 $\mathrm{IC}_{50}$ 값이 $20.9 \pm 0.5 \mu \mathrm{g} / \mathrm{mL}$ 로 상대적 으로 가장 우수한 저해 활성을 나타내었다.

\section{생성물질의 분취 및 정량분석}

60 분 플라즈마 처리된 녹차 반응물 $(155 \mathrm{mg})$ 을 ODS gel (YMC ODS AQ 120-50S, YMC Co., Kyoto, Japan)(1.0 cm i.d. $\times 40 \mathrm{~cm}, 50 \mu \mathrm{m}$ particle size)을 충진제로 활용한 칼럼크 로마토그래피 및 semi-preparative HPLC(YMC gel ODS A-323, $4.6 \mathrm{~mm} \times 150 \mathrm{~mm}, 5 \mu \mathrm{m}$ particle size)를 수행하여 화 합물 1 을 $3.0 \mathrm{mg}$, 화합물 2 을 $5.2 \mathrm{mg}$ 분리하였다. HPLC 분석 에 이동상 용매로 $0.1 \%$ formic acid(solvent $\mathrm{A}$ )와 acetonitrile (solvent $\mathrm{B}$ )를 사용하여 gradient elution을 $92 \% \mathrm{~A} ; 8 \% \mathrm{~B}$ 로 분석하여 $15 \mathrm{~min}, 50 \% \mathrm{~A} ; 50 \% \mathrm{~B}, 25 \mathrm{~min}, 0 \% \mathrm{~A} ; 100 \%$ 
$\mathrm{B}$ 의 용매조성으로 물질을 분석을 하였으며, 이동상의 유속은 $1.0 \mathrm{~mL} / \mathrm{min}$ 을 유지하였고 $280 \mathrm{~nm}$ 에서 화합물을 검출하였다 (Fig. 1). 녹차의 주요 화합물 및 플라즈마 처리 후 생성되는 화합물은 $\mathrm{HPLC}$ 를 이용하여 정량평가를 수행하였다. 각 화 합물은 $10-200 \mathrm{mg} / \mathrm{L}$ 의 농도로 제조하여 분석을 수행하였고, caffeine $\left(\mathrm{y}=9831.5 \mathrm{x}+68308, \mathrm{R}^{2}=0.9996\right), \mathrm{EGCG}(\mathrm{y}=5126.9 \mathrm{x}+$ $\left.30580, \mathrm{R}^{2}=0.9997\right), 1\left(\mathrm{y}=8240.7 \mathrm{x}-3694, \mathrm{R}^{2}=0.9992\right)$ 및 $2(\mathrm{y}=$ $\left.5258.5 \mathrm{x}-1403, \mathrm{R}^{2}=0.9999\right)$ 의 표준검량곡선을 이용하여 정량 하였다.

\section{AGEs 생성 저해활성 측정}

최종당화산물 생성 저해활성은 Vinson과 Howard(1996)가 행한 방법을 변형하여 실시하였다. $10 \mathrm{mg} / \mathrm{mL}$ 의 BSA를 0.2 $\mathrm{M}$ phosphate buffer(pH 7.4)에 용해시키고, $0.2 \mathrm{M}$ 의 fructose 와 glucose를 처리하였다. 이때 $0.2 \mathrm{M}$ phosphate buffer에 $0.02 \%$ sodium azide를 넣어 반응기간 동안 박테리아의 생성 을 방지하였다. 시료는 $10 \%$ 의 $\mathrm{DMSO}$ 에 녹여 준비하였으며, 이 반응액에 분리된 화합물 또는 양성 대조군인 aminoguanidine을 첨가한 후 $37^{\circ} \mathrm{C}$ 에서 7 일 동안 반응시켰다. 반응 후에는 ELISA reader(Infinite F200, Tecan Austria GmBH,

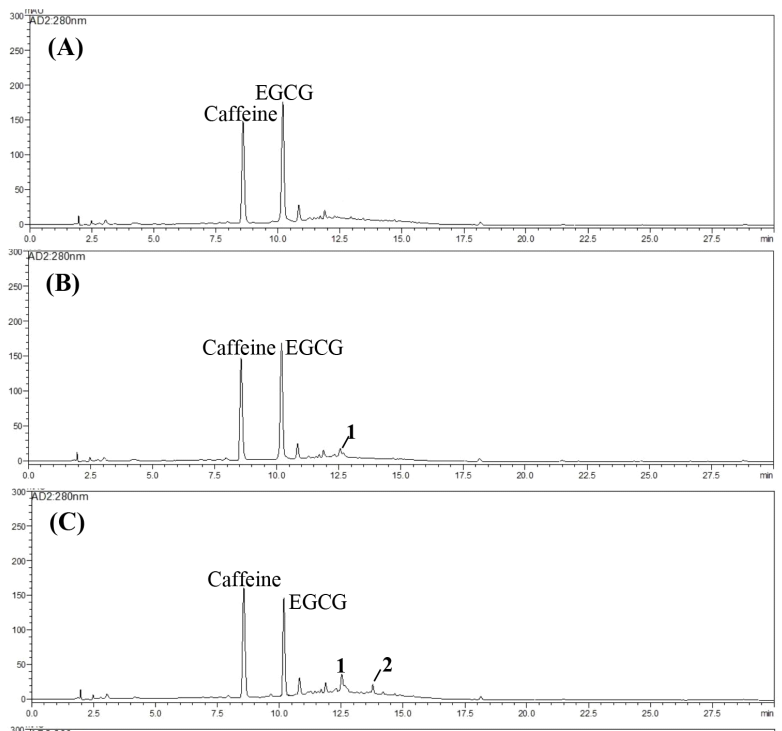

(D)

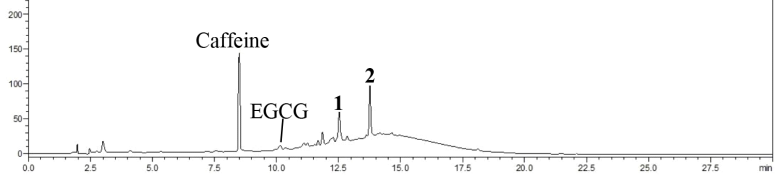

Fig. 1. HPLC chromatograms of plasma-treated green tea for three different times.

A, 0 (control); B, $20 \mathrm{~min}$; C, $40 \mathrm{~min}$; D, $60 \mathrm{~min}$.

1, Oolonhomobisflavan A; 2, oolonghomobisflavan B.
Grödig, Austria)를 이용하여 형광도(Ex: $350, \mathrm{Em:} 450 \mathrm{~nm}$ ) 를 측정하였다. $\mathrm{IC}_{50}$ 값은 시료가 $\mathrm{AGEs}$ 생성을 $50 \%$ 저해하 는 농도로 나타내었다.

\section{Hydroxyl 라디칼 소거활성 측정}

플라즈마 처리된 녹차 반응물 및 신규 생성된 화합물은 deoxyribose 방법 $(\mathrm{Li}, 2013)$ 을 변형하여 다음과 같이 측정하 였다. $2.5 \mathrm{mM}$ deoxyribose, $1.5 \mathrm{mM} \mathrm{H}_{2} \mathrm{O}_{2}, 100 \mu \mathrm{M} \mathrm{FeCl}_{3}$ 및 $100 \mu \mathrm{M}$ EDTA를 $10 \mu \mathrm{mM}$ phosphate buffer(pH 7.4)에 녹 인 후 농도 별로 제조한 시료에 첨가한다. 반응 시작 전 100 $\mu \mathrm{M}$ ascorbic acid를 첨가한 후 $37^{\circ} \mathrm{C}$ 에서 1 시간 동안 반응시킨 다. 반응 후 $0.5 \%$ thiobarbituric acid와 $2.8 \%$ trichloroacetic $\mathrm{acid}$ 를 첨가한 후 $80^{\circ} \mathrm{C}$ 의 온도에서 20 분 동안 가열한다. 이후 급속 냉각시킨 후 ELISA reader를 이용하여 $532 \mathrm{~nm}$ 에서 흡 광도를 측정한다. 이때 양성 대조군은 천연 항산화제인 (+)-catechin을 사용하였다. $\mathrm{IC}_{50}$ 값은 시료가 hydroxyl 라디칼 을 $50 \%$ 저해하는 농도로 나타내었다.

\section{통계처리}

실험결과는 SPSS package program(version 20.0, SPSS Inc., Chicago, IL, USA)을 이용하여 각 실험군 간의 유의성 을 검증한 후 Duncan's multiple range test에 의해 실험군 간 의 차이를 $\mathrm{p}<0.05$ 유의수준에서 검증하였다.

\section{결과 및 고찰}

\section{플라즈마 처리로 신규 생성된 화합물의 분리}

녹차 추출물을 에탄올에 녹인 후 저온 플라즈마 처리 기기 를 이용하여 20, 40 및 60 분 동안 플라즈마 처리 후 농축하였 으며, 시간별 처리된 녹차 반응물을 항당화 및 항산화 활성 평가를 수행하였다(Table 1). 먼저 녹차 추출물(무처리군)의 $\mathrm{AGEs}$ 생성 저해능의 $\mathrm{IC}_{50}$ 값은 $62.6 \pm 0.3 \mu \mathrm{g} / \mathrm{mL}$ 의 활성을 나 타내었으며, 20 및 40 분 동안 플라즈마 처리된 녹차 반응물 의 경우 $\mathrm{IC}_{50}$ 값이 각 $55.7 \pm 0.9$ 및 $43.0 \pm 0.4 \mu \mathrm{g} / \mathrm{mL}$ 로 대조군 에 비해 조금 상승된 저해 활성을 나타내었다. 60 분 동안 플 라즈마 처리된 녹차 반응물의 $\mathrm{IC}_{50}$ 값은 $20.9 \pm 0.5 \mu \mathrm{g} / \mathrm{mL}$ 로 녹 차 추출물에 비해 월등히 상승된 AGEs 생성 저해능을 나타내 었다. Hydroxyl 라디칼 소거능 평가에서도 역시 60분 동안 플 라즈마 처리된 녹차 반응물에서 $\mathrm{IC}_{50}$ 값이 $6.9 \pm 0.2 \mu \mathrm{g} / \mathrm{mL}$ 로 녹 차 추출물 $\left(\mathrm{IC}_{50}: 15.5 \pm 0.4 \mu \mathrm{g} / \mathrm{mL}\right)$ 에 비해 2배 이상 상승된 라 디칼 소거 활성을 나타내었다. 녹차 추출물 및 플라즈마 처리 된 녹차 반응물을 $\mathrm{HPLC}$ 를 이용하여 비교 분석을 수행한 결 과, 녹차의 주요 성분인 $\mathrm{EGCG}\left(t_{\mathrm{R}}: 10.2 \mathrm{~min}\right)$ 가 플라즈마 처 리시 감소하는 경향을 나타내었고, 플라즈마 처리된 녹차 반 
Table 1. Effects on AGEs formation and hydroxyl radical scavenging activities of plasma-treated green tea for each times

\begin{tabular}{ccc}
\hline \multirow{2}{*}{$\begin{array}{c}\text { Treatment time } \\
(\text { min })\end{array}$} & \multicolumn{2}{c}{ IC $_{50}$ values $(\mu \mathrm{g} / \mathrm{mL})^{1)}$} \\
\cline { 2 - 3 } & AGEs formation $^{2)}$ & Hydroxyl radical $^{3)}$ \\
\hline 0 (Control) & $62.6 \pm 0.3^{\mathrm{a}}$ & $15.5 \pm 0.4^{\mathrm{x}}$ \\
20 & $55.7 \pm 0.9^{\mathrm{a}}$ & $14.1 \pm 0.3^{\mathrm{x}}$ \\
40 & $43.0 \pm 0.4^{\mathrm{b}}$ & $10.6 \pm 0.2^{\mathrm{y}}$ \\
60 & $20.9 \pm 0.5^{\mathrm{c}}$ & $6.9 \pm 0.2^{\mathrm{z}}$ \\
\hline
\end{tabular}

${ }^{1)}$ Data represent the mean \pm SD three replications.

${ }^{2)}$ Different letters $\left({ }^{\mathrm{a}-\mathrm{c}}\right)$ within the same column indicate significant differences $(\mathrm{p}<0.05)$

${ }^{3)}$ Different letters $\left({ }^{\mathrm{x}-\mathrm{z}}\right)$ within the same column indicate significant differences $(\mathrm{p}<0.05)$

응물에서 새롭게 생성된 피크가 $t_{\mathrm{R}} 12.5$ 및 13.8 분에서 검출 되었다(Fig. 1). 플라즈마 처리된 녹차 반응물 $(60 \mathrm{~min})$ 에 대 해 ODS gel을 충진제로 이용한 칼럼그로마토그래피를 수행 하였으며, 화합물 $1\left(3.0 \mathrm{mg}, t_{\mathrm{R}} 12.5 \mathrm{~min}\right)$ 및 $2\left(5.2 \mathrm{mg}, t_{\mathrm{R}}\right.$ $13.8 \mathrm{~min}$ )를 분리하였고, 정제된 화합물을 ${ }^{1} \mathrm{H},{ }^{13} \mathrm{C} \mathrm{NMR}$, $\mathrm{HSQC}, \mathrm{HMBC}$ 등의 NMR과 FABMS 스펙트럼을 측정하여 화합물의 구조 결정을 수행하였다.

\section{화합물 1 및 2의 구조동정}

화합물 1 은 갈색 무결정형 가루 형태로 정제하였으며, FABMS 측정 결과 $m / z$ 927[M-H]'의 base peak를 확인하여 분자량을 추정하였다. ${ }^{1} \mathrm{H}$ 및 ${ }^{13} \mathrm{C} \mathrm{NMR}$ 측정한 결과(Table 2), 3 개의 aromatic proton signals이 $\delta_{\mathrm{H}} 7.11(4 \mathrm{H}, \mathrm{s}, \mathrm{H}-2 ", 6 ")$, $6.77\left(4 \mathrm{H}, \mathrm{H}-2^{\prime}, 6^{\prime}\right)$ 및 $6.10(2 \mathrm{H}, \mathrm{s}, \mathrm{H}-6)$ 에서 관찰되었고, 두
개의 oxygenated methaine signals이 $\delta_{\mathrm{H}} 5.52(2 \mathrm{H}, \mathrm{m}, \mathrm{H}-3)$ 및 $5.20(2 \mathrm{H}, \mathrm{brs}, \mathrm{H}-2)$, 한 개의 methylene proton이 $\delta_{\mathrm{H}} 3.07$ $(2 \mathrm{H}, \mathrm{m}, \mathrm{H}-4), 2.98(2 \mathrm{H}, \mathrm{m}, \mathrm{H}-4)$, 한 개의 carbonyl carbon signal이 $\delta_{\mathrm{C}} 166.5\left(\mathrm{C}-7^{\prime \prime}\right)$ 에서 관찰되어 $\mathrm{EGCG}$ 골격의 화합물 임 확인하였다. 추가적으로 한 개의 methylene signal이 $\delta_{\mathrm{H}}$ $3.98\left(2 \mathrm{H}, \mathrm{s},-\mathrm{CH}_{2}-\right)$ 및 $\delta_{\mathrm{C}} 16.3\left(-\mathrm{CH}_{2}-\right)$ 이 관찰되어 화합물 1 은 EGCG 2분자가 methylene-bridge로 결합되어 있음을 시 사하였다. $\mathrm{HMBC}$ 스펙트럼 측정 결과 methylene proton $\left(-\mathrm{CH}_{2}-\right)$ 이 C-7, 8,9 까지 $\mathrm{HMBC}$ 상관관계를 나타내었다. 또 한 H-2 및 H-4이 C-9까지 HMBC 상관관계의 cross peak를 확인하여 화합물 1은 EGCG의 C-8 위치에서 methylene으로 결합된 EGCG 이량체 화합물인 oolonghomobisflavan A로 구조 동정하였다(Hashimoto 등, 1989).

화합물 2 역시 갈색의 무결정형 가루 형태로 분리하였고, FABMS 및 1D NMR 측정한 결과, 화합물 1 과 매우 유사한 형태의 signals을 나타내었다. 또한, 화합물 2 역시 $\delta_{\mathrm{H}} 3.87$ $\left(2 \mathrm{H}, \mathrm{s},-\mathrm{CH}_{2}-\right)$ 및 $\delta_{\mathrm{C}} 17.0\left(-\mathrm{CH}_{2}-\right)$ 이 관찰되어 화합물 1 의 구 조 이성질체 화합물임을 시사하였다. 2D NMR 데이터 해석 결과, 화합물 2는 $\mathrm{EGCG}$ 의 각 $\mathrm{C}-6$ 및 8 위치에서 methylene 으로 결합된 oolonghomobisflavan $\mathrm{B}$ 로 구조 동정하였으며 (Hashimoto 등, 1989), 구조는 Fig. 2에 나타내었다. 이전 연 구에서 화합물 1 및 2는 우롱차(oolong tea)로부터 최초로 분 리 및 구조 동정되었고(Hashimoto 등, 1989), 항비만과 관련 된 pancreatic lipase 효소 저해 활성 평가에서 우수한 활성이 보고가 되었다(Nakai 등, 2005). 하지만 당뇨 합병증과 관련 된 기능성 평가에 대한 연구 결과는 없었다. 이에 분리된 순 수한 단일물질 1 및 2에 대해 AGEs 생성 저해 활성 및 hydroxyl 라디칼 소거 활성 평가를 수행하였다.

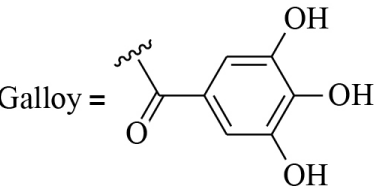<smiles>CO[C@@H]1Cc2c(O)cc(O)c(Cc3c(O)cc(O)c4c3O[C@H](c3cc(O)c(O)c(O)c3)C(O)C4)c2O[C@H]1c1cc(O)c(O)c(O)c1</smiles>

Oolonghomobisflavan A (1)<smiles>CO[C@@H]1C[C@@H](c2cc(O)c(O)c(O)c2)Oc2c(Cc3c(O)cc4c(c3O)C[C@@H](OC)[C@@H](c3cc(O)c(O)c(O)c3)O4)c(O)cc(O)c21</smiles>

Oolonghomobisflavan B (2)

Fig. 2. Chemical structures of newly generated products 1 and 2 from plasma-treated green tea. 
Table 2. ${ }^{1} \mathrm{H}$ and ${ }^{13} \mathrm{C}$ NMR sectral data of compounds 1 and $2^{1)}$

\begin{tabular}{|c|c|c|c|c|c|c|}
\hline \multirow{2}{*}{ Position } & \multicolumn{2}{|c|}{ Oolonghomobisflavan A (1) } & \multicolumn{4}{|c|}{ Oolonghomobisflavan B (2) } \\
\hline & $\delta_{\mathrm{H}}$ & $\delta_{\mathrm{C}}$ & $\delta_{\mathrm{H}}$-Upper & $\delta_{\mathrm{C}}$-Upper & $\delta_{\mathrm{H}}$-Lower & $\delta_{\mathrm{C}}$-Lower \\
\hline 2 & 5.20 (br s) & 79.5 & 4.99 (br s) & 77.8 & 5.29 (br s) & 79.6 \\
\hline 3 & $5.52(\mathrm{~m})$ & 69.3 & $5.48(\mathrm{~m})$ & 68.9 & $5.57(\mathrm{~m})$ & 69.3 \\
\hline 4 & $3.07(\mathrm{~m}), 2.98(\mathrm{~m})$ & 26.9 & $3.05(\mathrm{~m}), 2.88(\mathrm{~m})$ & 26.5 & $3.08(\mathrm{~m}), 2.97(\mathrm{~m})$ & 26.9 \\
\hline 5 & - & 152.6 & - & 154.1 & - & 152.5 \\
\hline 6 & $6.10(\mathrm{~s})$ & 97.4 & - & 105.8 & $6.15(\mathrm{~s})$ & 97.1 \\
\hline 7 & - & 155.6 & - & 154.3 & - & 154.3 \\
\hline 8 & - & 105.5 & $6.12(\mathrm{~s})$ & 96.2 & - & 107.2 \\
\hline 9 & - & 155.8 & - & 155.5 & - & 154.9 \\
\hline 10 & - & 99.3 & - & 99.7 & - & 100.2 \\
\hline $1^{\prime}$ & - & 129.7 & - & 129.3 & - & 130.5 \\
\hline $2^{\prime}$ & $6.77(\mathrm{~s})$ & 106.8 & $6.60(\mathrm{~s})$ & 106.6 & $6.77(\mathrm{~s})$ & 106.5 \\
\hline $3^{\prime}$ & - & 145.9 & - & 146.2 & - & 146.0 \\
\hline $4^{\prime}$ & - & 133.5 & - & 132.8 & - & 133.4 \\
\hline $5^{\prime}$ & - & 145.9 & - & 146.2 & - & 146.0 \\
\hline $6^{\prime}$ & $6.77(\mathrm{~s})$ & 106.8 & $6.60(\mathrm{~s})$ & 106.6 & $6.77(\mathrm{~s})$ & 106.5 \\
\hline $1 "$ & - & 121.5 & - & 121.4 & - & 121.5 \\
\hline $2 "$ & $7.11(\mathrm{~s})$ & 110.3 & $6.99(\mathrm{~s})$ & 109.7 & $7.08(\mathrm{~s})$ & 109.9 \\
\hline $3 "$ & - & 146.4 & - & 145.6 & - & 145.7 \\
\hline $4 "$ & - & 139.0 & - & 138.6 & - & 138.5 \\
\hline $5^{\prime \prime}$ & - & 146.4 & - & 145.6 & - & 145.7 \\
\hline $6 "$ & $7.11(\mathrm{~s})$ & 110.3 & $6.99(\mathrm{~s})$ & 109.7 & $7.08(\mathrm{~s})$ & 109.9 \\
\hline $7^{\prime \prime}$ & & 166.5 & - & 166.0 & - & 166.1 \\
\hline$-\mathrm{CH}_{2^{-}}$ & $3.98(\mathrm{~s})$ & 16.3 & $3.87(\mathrm{~s})$ & 17.0 & & \\
\hline
\end{tabular}

${ }^{1) 1} \mathrm{H}$ NMR spectra were measured at $600 \mathrm{MHz}$, and ${ }^{13} \mathrm{C}$ NMR spectra were measured at $150 \mathrm{MHz}$, Data obtained in acetone- $d_{6}+\mathrm{D}_{2} \mathrm{O}$. Assignments based on HSQC and HMBC spectra data.

\section{단일물질의 AGEs 생성 저해 및 hydroxyl 라디칼 소거 활성}

녹차 추출물에 플라즈마 처리시 신규 생성된 oolonghomobisflavan $\mathrm{B}(2)$ 는 $\mathrm{AGEs}$ 생성 저해능의 $\mathrm{IC}_{50}$ 값이 $13.1 \pm 1.0 \mu \mathrm{M}$ 으로 우수한 활성을 나타내었다(Table 3). 화합물 2의 구조 이성질체 화합물인 oolonghomobisflavan $\mathrm{A}(1)$ 의 $\mathrm{IC}_{50}$ 값은 $8.2 \pm 0.5 \mu \mathrm{M}$ 으로 $\mathrm{AGEs}$ 생성 저해 활성을 나타내었으며, 화 합물 1 및 2는 양성대조군으로 사용된 aminoguanidine $\left(\mathrm{IC}_{50}\right.$ : $986.1 \pm 2.6 \mu \mathrm{M})$ 의 AGES 생성 저해 활성에 비해 우수한 활성 임을 확인하였다. Hydroxyl 라디칼 소거능 평가에서도 역시 녹차의 주요 성분인 $\mathrm{EGCG}\left(\mathrm{IC}_{50}: 56.1 \pm 1.0 \mu \mathrm{M}\right)$ 보다 플라즈
마 처리로 신규 생성된 oolonghomobisflavans $\mathrm{A}(1)$ 및 $\mathrm{B}(2)$ 의 $\mathrm{IC}_{50}$ 값이 각 $13.3 \pm 0.6$ 및 $22.8 \pm 0.9 \mu \mathrm{M}$ 으로 월등히 상승된 라디칼 소거 활성을 나타내었다(Table 3).

이전 연구에서 백차(Camellia sinensis)로부터 alkaloid가 결합된 EGCG 유도체가 구조 동정되었으며, 우수한 AGEs 생성 저해활성을 나타내었다( $\mathrm{Li}$ 등, 2018). 또한, $\mathrm{EGCG}$ 와 fatty acid를 합성하여 신규 생성된 lipophilized EGCG 유도 체가 우수한 항당화 및 항산화 활성이 보고되었다(Wang 등, 2016b; Zhong과 Shahidi, 2011). 본 연구에서는 녹차에 저온 플라즈마를 처리한 결과, 신규 생성된 EGCG 유래 이랑체 화 
Table 3. Effects on AGEs formation and hydroxyl radical scavenging activities of newly generated 1 and 2 from plasma-treated green tea

\begin{tabular}{ccc}
\hline \multirow{2}{*}{ Compounds } & \multicolumn{2}{c}{$\mathrm{IC}_{50}$ values $(\mu \mathrm{M})$} \\
\cline { 2 - 3 } & AGEs formation & Hydroxyl radical \\
\hline EGCG & $108.1 \pm 1.2^{1 \mathrm{~b} 2)}$ & $\left.56.1 \pm 1.0^{\mathrm{x} 3}\right)$ \\
1 & $8.2 \pm 0.5^{\mathrm{d}}$ & $13.3 \pm 0.6^{\mathrm{z}}$ \\
2 & $13.1 \pm 1.0^{\mathrm{c}}$ & $22.8 \pm 0.9^{\mathrm{y}}$ \\
Aminoguanidine $^{4)}$ & $986.1 \pm 2.6^{\mathrm{a}}$ & $\left.-^{5}\right)$ \\
(+)-Catechin $^{4)}$ & - & $81.0 \pm 1.0^{\mathrm{w}}$
\end{tabular}

${ }^{1)}$ Data represent the mean \pm SD three replications.

${ }^{2}$ Different letters $\left({ }^{\mathrm{a}-\mathrm{d}}\right)$ within the same column indicate significant differences $(\mathrm{p}<0.05)$.

${ }^{3)}$ Different letters $\left.{ }^{(\mathrm{W}-\mathrm{z}}\right)$ within the same column indicate significant differences $(p<0.05)$

${ }^{4)}$ Positive control.

${ }^{5)}$ Not tested.

합물들의 구조를 동정하였으며, 우수한 항당화 및 항산화 활 성을 나타내었다. 향후 추가적인 세포 및 동물실험을 통해 $\mathrm{EGCG}$ 이량체 화합물의 활성 기작에 대한 연구가 필요하다 고 사료된다.

\section{플라즈마 처리된 녹차 반응물의 정량평가}

녹차의 주요 성분인 caffeine 및 $\mathrm{EGCG}$ 와 플라즈마 처리로 신규 생성된 화합물 1 및 2에 대해 HPLC 분석을 이용하여 정 량평가를 수행하였다(Table 4). 녹차에는 caffeine이 $110.7 \pm 1.6$ $\mathrm{mg} / \mathrm{g}$ 이 함유되어 있으며, 20,40 및 60 분 동안 플라즈마 처 리된 녹차 반응물에서 $108.7-109.6 \mathrm{mg} / \mathrm{g}$ 의 함량으로 유의적 인 차이를 나타내지 않았다. EGCG는 녹차 추출물에 $1 \mathrm{~g}$ 당 $150.6 \pm 1.5 \mathrm{mg}$ 이 함유되어 있었지만 20,40 및 60 분 동안 플 라즈마 처리한 녹차 반응물에서 각 $124.4 \pm 0.8,87.8 \pm 1.0$ 및 $14.7 \pm 1.7 \mathrm{mg} / \mathrm{g}$ 으로 플라즈마 처리 시간이 증가함에 따라 $\mathrm{EGCG}$ 의 함량이 감소하는 경향을 나타내었다. 플라즈마 처 리에 의해 신규 생성된 화합물 1 의 경우, 20 분 플라즈마 처리
된 녹차 반응물에서 $14.2 \pm 0.6 \mathrm{mg} / \mathrm{g}$ 을 나타내었으며, 60 분 플 라즈마 처리된 녹차 반응물에서 $20.4 \pm 1.1 \mathrm{mg} / \mathrm{g}$ 으로 플라즈마 처리시간이 증가함에 따라 함량이 증가하는 경향을 확인하였 다. 화합물 2 의 경우, 60 분 처리된 녹차 반응물에서 $49.9 \pm 0.7$ $\mathrm{mg} / \mathrm{g}$ 으로 caffeine 다음으로 가장 많이 함유되어 있음을 확 인하였다. 녹차에 플라즈마 처리할 시 caffeine의 함량에는 큰 영향을 주지 않았으나, 주요 화합물인 $\mathrm{EGCG}$ 의 함량은 상 대적으로 감소하였으며, EGCG로부터 화합물 1 및 2가 플라 즈마 처리에 의해 새롭게 생성되는 것을 확인하였다.

이전 연구에서 에탄올을 플라즈마 처리할 경우 $\mathrm{H} \cdot$, $\mathrm{CH}_{2} \mathrm{OH}$ - 및 $\mathrm{CHO}$ - 등의 라디칼이 생성됨이 보고되었으며 (Wang 등, 2016a), 참기름의 주요 lignan 성분인 sesamol을 에탄올 용액 상태에서 플라즈마 처리 시 에탄올 유래의 methylene 가교에 의한 sesamol 이량체의 생성 및 생성기작 이 보고되었다(Jeong 등, 2020). 본 연구에서도 같은 기작에 의해 플라즈마 처리 시 생성되는 라디칼에 의해 녹차의 주요 성분인 $\mathrm{EGCG}$ 이량체 화합물의 생성이 시사되었으며, AGEs 생성 저해 및 hydroxyl 라디칼 소거 활성 상승과 싶은 상관관 계가 있음을 확인하였다.

\section{요 약}

녹차의 플라즈마 처리 시 주요 성분의 변화 및 당뇨합병증 관련 효능변화를 검증하기 위하여 본 연구를 수행하였으며, 녹차 추출물을 에탄올에 녹인 후 20,40 및 60 분 동안 플라즈 마 처리 후 AGEs 생성 저해능 및 hydroxyl 라디칼 소거 활성 평가를 수행하였다. 플라즈마 처리 시간이 증가함에 따라 AGEs 생성 저해능은 상승하는 경향을 나타내었으며, hydroxyl 라디칼 소거능 평가에서도 60 분 플라즈마 처리된 녹차 반응 물에서 $\mathrm{IC}_{50}$ 값이 $6.9 \pm 0.2 \mu \mathrm{g} / \mathrm{mL}$ 로 무처리군( IC $_{50}: 15.5 \pm 0.4 \mu$ $\mathrm{g} / \mathrm{mL}$ )에 비해 월등히 상승된 활성을 나타내었다. 이에 녹차 의 주요 성분인 EGCG로부터 플라즈마 처리에 의해 생성된 물질에 대해 각종 칼럼크로마토그래피 및 기기분석을 활용하

Table 4. The content $(\mathrm{mg} / \mathrm{g})$ of individual components in green tea extract by plasma treatment times

\begin{tabular}{cccccc}
\hline \multirow{2}{*}{ Compounds } & $t_{\mathrm{R}}(\mathrm{min})$ & \multicolumn{4}{c}{ Plasma treatment time $(\mathrm{min})$} \\
\cline { 3 - 6 } & & 0 (control) & 20 & 40 & 60 \\
\hline Caffeine & 8.6 & $110.7 \pm 1.6^{\mathrm{b} 1)}$ & $109.5 \pm 1.0^{\mathrm{b}}$ & $108.7 \pm 0.9^{\mathrm{b}}$ & $109.6 \pm 1.0^{\mathrm{b}}$ \\
EGCG & 10.2 & $150.6 \pm 1.5^{\mathrm{a}}$ & $124.4 \pm 0.8^{\mathrm{b}}$ & $87.8 \pm 1.0^{\mathrm{c}}$ & $14.7 \pm 1.7^{\mathrm{e}}$ \\
1 & 12.5 & $\mathrm{ND}^{2)}$ & $14.2 \pm 0.6^{\mathrm{e}}$ & $18.9 \pm 0.9^{\mathrm{e}}$ & $20.4 \pm 1.1^{\mathrm{e}}$ \\
2 & 13.8 & $\mathrm{ND}$ & $\mathrm{ND}$ & $12.7 \pm 0.8^{\mathrm{e}}$ & $49.9 \pm 0.7^{\mathrm{d}}$ \\
\hline
\end{tabular}

${ }^{1)}$ All tested samples were examined in triplicated experiments. Means with different letters $\left({ }^{\mathrm{a}-\mathrm{e}}\right)$ within the column differ significantly $(\mathrm{p}<0.05)$ ${ }^{2)} \mathrm{ND}$, not detected. 
여 2종의 EGCG 이량체 화합물을 분리하였고, 각 화합물들 의 구조는 NMR 및 FABMS 스펙트럼 분석으로 oolonghomobisflavans $\mathrm{A}(1)$ 및 $\mathrm{B}(2)$ 로 구조 동정하였다. 분리된 단일 물질을 대해 AGEs 생성 저해능 및 hydroxyl 라디칼 소거능 평가를 수행하였다. EGCG의 C-8 위치에서 methylene-bridge 로 결합된 화합물 1 의 경우 $\mathrm{IC}_{50}$ 값이 $8.2 \pm 0.5 \mu \mathrm{M}$ 으로 우수한 AGEs 생성 저해 활성을 나타내었으며, hydroxyl 라디칼 소 거능에서도 $\mathrm{IC}_{50}$ 값이 $13.3 \pm 0.6 \mu \mathrm{M}$ 으로 강한 라디칼 소거 활 성을 나타내었다. 화합물 1의 구조이성질체 화합물인 oolonghomobisflavan $\mathrm{B}(2)$ 는 화합물 1 에 비해 상대적으로 낮은 활 성을 나타내었으나, 양성대조군으로 사용된 aminoguanidine 및 (+)-catechin에 비해 우수한 활성임을 확인하였다. 녹차 추 출물에서는 화합물 1 및 2 가 검출되지 않았지만, 플라즈마 처 리된 녹차 반응물에서 검출되었으며, 특히 60 분 동안 처리된 반응물에서 각 $20.4 \pm 1.1$ 및 $49.9 \pm 0.7 \mathrm{mg} / \mathrm{g}$ 의 함량을 확인하 였다. 이상의 연구 결과로부터 녹차에 플라즈마 처리는 주요 성분인 EGCG 유래 이량체 화합물인 1 및 2의 생성을 유도하 였으며, EGCG보다 우수한 AGEs 생성 저해능 및 hydroxyl 라디칼 소거능을 나타내었다. 향후 플라즈마 처리시 식품의 주요 성분들의 구조 변환 양상과 기능성 상승과 관련하여 다 양한 조건에서 체계적인 연구가 필요하다고 생각된다.

\section{감사의 글}

이 논문은 2020년도 정부 출연 재원으로 국가핵융합연구소 주요 사업 중 '미래선도 플라즈마-농식품 선도기술(Plasma Farming)개발' 관련 사업에서 지원을 받아 수행된 연구임.

\section{Conflict of interests}

The authors declare no potential conflict of interest.

\section{ORCID}

Gyeong Han Jeong

https://orcid.org/0000-0001-7115-4945

Tae Hoon Kim https://orcid.org/0000-0003-0428-2829

\section{References}

Ahmed N. Advanced glycation endproducts-role in pathology of diabetic complications. Diabetes Res Clin Pract, 67, 3-21 (2004)

Azam S, Hadi N, Khan NU, Hadi SM. Prooxidant property of green tea polyphenols epicatechin and epigalloca- techin-3-gallate: Implications for anticancer properties. Toxicol In Vitro, 18, 555-561 (2005)

Cho SJ, Roman G, Yeboah F, Konishi, Y. The road to advanced glycation end products: a mechanistic perspective. Curr Med Chem, 14, 1653-1671 (2007)

Hashimoto F, Nonaka GI, Nishioka I. Tannins and related compounds. XC.: 8-C-ascorbyl (-)-epigallocatechin 3-Ogallate and novel dimeric flavan-3-ols, oolonghomobisflavans A and B, from oolong tea.(3). Chem Pharm Bull, 37, 3255-3263 (1989)

Hou Y, Wang R, Gan Z, Shao T, Zhang X, He M, Sun A. Effect of cold plasma on blueberry juice quality. Food Chem, 290, 79-86 (2019)

Hu J, Webster D, Cao J, Shao A. The safety of green tea and green tea extract consumption in adults-Results of a systematic review. Regul Toxicol Pharmacol, 95, 412-433 (2018)

Ito H, Li P, Koreishi M, Nagatomo A, Nishida N, Yoshida T. Ellagitannin oligomers and a neolignan from pomegranate arils and their inhibitory effects on the formation of advanced glycation end products. Food Chem, 152, 323-330 (2014)

Jang DS, Lee GY, Lee YM, Kim YS, Sun H, Kim DH, Kim JS. Flavan-3-ols having a $\gamma$-lactam from the roots of Actinidia arguta inhibit the formation of advanced glycation end products in vitro. Chem Pharm Bull, 57, 397-400 (2009)

Jeong YH, Jeong GH, Jeong YH, Kim TH. Identification of sesamol byproducts produced by plasma treatment with inhibition of advanced glycation endproducts formation and $\mathrm{ONOO}^{-}$scavenging activities. Food Chem, 314, 126196 (2020)

Ji SH, Ki SH, Ahn JH, Shin JH, Hong EJ, Kim YJ, Choi EH. Inactivation of Escherichia coli and Staphylococcus aureus on contaminated perilla leaves by dielectric barrier discharge (DBD) plasma treatment. Arch Biochem Biophys, 643, 32-41 (2018)

Kis M, Milosevic S, Vulic A, Herceg Z, Vukusic T, Pleadin J. Efficacy of low pressure DBD plasma in the reduction of T-2 and HT-2 toxin in oat flour. Food Chem, 316, 126372 (2020)

Kovacevic DB, Putnik P, Dragovic-Uzelac V, Pedisić S, Jambrak AR, Herceg Z. Effects of cold atmospheric gas phase plasma on anthocyanins and color in pomegranate 
juice. Food Chem, 190, 317-323 (2016)

Lambert JD, Sang S, Hong J, Yang CS. Anticancer and anti-inflammatory effects of cysteine metabolites of the green tea polyphenol, (-)-epigallocatechin-3-gallate. J Agric Food Chem, 58, 10016-10019 (2010)

Lee NY, Jo C, Sohn SH, Kim JK, Byun MW. Effects of gamma irradiation on the biological activity of green tea byproduct extracts and a comparison with green tea leaf extracts. J Food Sci, 71, C269-C274 (2006)

Li X. Solvent effects and improvements in the deoxyribose degradation assay for hydroxyl radical-scavenging. Food Chem, 141, 2083-2088 (2013)

Li X, Liu GJ, Zhang W, Zhou YL, Ling TJ, Wan XC, Bao GH. Novel flavoalkaloids from white tea with inhibitory activity against the formation of advanced glycation end products. J Agric Food Chem, 66, $4621-4629$ (2018)

Matsuda H, Wang T, Managi H, Yoshikawa M. Structural requirements of flavonoids for inhibition of protein glycation and radical scavenging activities. Bioorg Med Chem, 11, 5317-5323 (2003)

Mineharu Y, Koizumi A, Wada Y, Iso H, Watanabe Y, Date C, Yamamoto A, Kikuchi S, Inada Y, Toyoshima $\mathrm{H}$, Kondo T, Tamakoshi A. Coffee, green tea, black tea and oolong tea consumption and risk of mortality from cardiovascular disease in Japanese men and women. J Epidemiol Commun Health, 65, 230-240 (2011)

Misra NN, Tiwari BK, Raghavarao KSMS, Cullen PJ. Nonthermal plasma inactivation of food-borne pathogens. Food Eng Rev, 3, 159-170 (2011)

Nakai M, Fukui Y, Asami S, Toyoda-Ono Y, Iwashita T, Shibata H, Mitsunaga T, Hashimoto F, Kiso Y. Inhibitory effects of oolong tea polyphenols on pancreatic lipase in vitro. J Agric Food Chem, 53, 4593-4598 (2005)

Oehmigen K, Hahnel M, Brandenburg R, Wilke C, Weltmann $\mathrm{KD}$, von Woedtke $\mathrm{T}$. The role of acidification for antimicrobial activity of atmospheric pressure plasma in liquids. Plasma Processes Polym, 7, 250-257 (2010)

Pankaj SK, Wan Z, Keener KM. Effects of cold plasma on food quality: A review. Foods, 7, 4 (2018)

Rahimi R, Nikfar S, Larijani B, Abdollahi M. A review on the role of antioxidants in the management of diabetes and its complications. Biomed Pharmacother, 59, 365373 (2005)

Seeram NP, Henning SM, Niu Y, Lee R, Scheuller HS, Heber D. Catechin and caffeine content of green tea dietary supplements and correlation with antioxidant capacity. J Agric Food Chem, 54, 1599-1603 (2006)

Shin MK. The status and prospect of Korean green tea. Food Science and Industry, 22, 13-20 (1989)

Singh R, Barden A, Mori T, Beilin L. Advanced glycation end-products: A review. Diabetologia, 44, 129-146 (2001)

Vinson JA, Howard III TB. Inhibition of protein glycation and advanced glycation end products by ascorbic acid and other vitamins and nutrients. J Nutr Biochem, 7, 659-663 (1996)

Wanasundara UN, Shahidi F. Antioxidant and pro-oxidant activity of green tea extracts in marine oils. Food Chem, 63, 335-342 (1998)

Wang B, Sun B, Zhu X, Yan Z, Liu Y, Liu H, Liu, Q. Hydrogen production from alcohol solution by microwave discharge in liquid. Int J Hydrogen Energy, 41, 7280-7291 (2016a)

Wang M, Zhang X, Zhong YJ, Perera N, Shahidi F. Antiglycation activity of lipophilized epigallocatechin gallate (EGCG) derivatives. Food Chem, 190, 1022-1026 (2016b)

Zhong Y, Shahidi F. Lipophilized epigallocatechin gallate (EGCG) derivatives as novel antioxidants. J Argic Food Chem, 59, 6526-6533 (2011) 